\title{
PERLAWANAN TERHADAP DOMINASI KEKUASAAN DALAM NOVEL PASUNG JIWA KARYA OKKY MADASARI (ANALISIS WACANA KRITIS)
}

\author{
Rini Idayatiningsih \\ SMA Negeri 16 Surabaya \\ $\underline{\text { rini@gmail.com }}$
}

\begin{abstract}
ABSTRAK
Fokus penelitian ini adalah mendeskripsikan (1) kosa kata, gramatika, dan struktur teks perlawanan terhadap dominasi kekuasaan dalam novel Pasung Jiwa karya Okky Madasari, (2) konteks situasi dan makna ujaran perlawanan terhadap dominasi kekuasaan dalam novel Pasung Jiwa karya Okky Madasari, dan (3) sosiobudaya perlawanan terhadap dominasi kekuasaan dalam novel Pasung Jiwa karya Okky Madasari.Penelitian ini menggunakan teori perlawanan Scoot yang ditunjang dengan teori kekuasaan Pierre Bourdeu. Jenis penelitian ini kualitatif dengan pendekatan analisis wacana kritis. Sumber data penelitian ini yaitu novel Pasung Jiwa karya Okky Madasari. Data penelitiannya berupa kalimat dan penggalan alinea. Teknik pengumpulan data dalam penelitian ini adalah teknik dokumentasi. Teknik analisis datanya menggunakan metode interaktif Miles Huberman yang berupa tiga tahap, yakni tahap reduksi data, penyajian data, dan penarikan kesimpulan serta verifikasi. Hasil penelitian ini menunjukkan beberapa hal. (1) Dilihat dari dimensi teks (mikrostruktural), aspek kelinguistikan memperlihatkan bahwa perlawanan dilakukan melalui kosa kata, gramatika, dan struktur teks yang membentuk kesatuan wacana. Perlawanan dalam aspek kelinguistikan tersebut berbentuk ideologi yang diperjuangkan dan direpresentasikan oleh kosa kata pada nilai representasional, nilai relasional, dan nilai ekspresif. (1) Dilihat dari dimensi praksis kewacanaan (mesostruktural), menyuarakan perlawanan melalui kontribusi proses produksi dan konsumsi teks, pengarang berpengaruh pada pemroduksian teks, sedangkan konsumen memaknai wacana tersebut sebagai bentuk perlawanan terhadap ketidakbebasan, ketidakadilan dan kesewenang-wenangan. c) Dilihat dari dimensi praksis sosiokultural (makrostruktural), konteks sosial budaya yang ada di luar teks berpengaruh pada munculnya teks. Secara situasional, Novel Pasung Jiwa bisa menjadi semacam cermin untuk menjadi seorang pemimpin yang bijak.
\end{abstract}

Kata kunci: analisis wacana kritis, kekuasaan, perlawanan

ABSTRACT

The focus of this study describe: vocabulary, grammar, and structure of the text of resistance to domination in the novel Pasung Jiwa by Okky Madasari, (2) the situational context and meaning of utterances resistance to domination in the novel Pasung Jiwa by Okky Madasari, and (3) sociocultural resistance to domination in the novel Pasung Jiwa by Okky Madasari. This study uses the Scoot theory of resistance supported by Pierre Bourdeu power theory. This is qualitative research 
with a critical discourse analysis approach. The data source of this research is the novel Pasung Jiwa by Okky Madasari. Data of the research are in the form of sentences and paragraphs fragment. Data collection techniques in this study is documentation techniques. Data analysis techniques uses interactive methods Miles Huberman in the form of three stages, namely stage data reduction, data presentation, and conclusion and verification. The results showed: Critical discourse analysis covering; a.) Dimension Text (microstructural), linguistics aspect shows that the resistance is done through the vocabulary, grammar, and structure of the text which form a unified discourse. Resistance in the form of linguistics aspect of ideology championed and represented by the value of the vocabulary on representational, relational values, and expressive value. b.) Dimensions of Praxis discourse (Mesostructural), voicing strong opposition through the contribution of the production and consumption of the text, the author produces effect on text, while consumers make sense of the discourse as a form of resistance against the lack of freedom, injustice and arbitrariness. c) Praxis Sociocultural Dimensions (Makrostruktural), socio-cultural contexts that exist outside the text affect the appearance of text. Situationally, Pasung Jiwa can be like a mirror to be a wise leader.

Keywords: critical discourse analysis, power, opposition

PENDAHULUAN atau doktrin yang dapat menyiksa dirinya sendiri.

Ketidakbebasan sangat berkaitan erat dengan kekuasaan. Kekuasaan adalah konsep penting dalam setiap kajian fenomena sosial.Kekuasaan amat berpengaruh terhadap kehidupan manusia. Kekuasaan sering diwujudkan melalui bahasa, bahkan dilaksanakan melalui bahasa. Bahasa digunakan oleh si kuat untuk mendominasi si lemah.Pengaruh kekuasaan itu tampak mulai dari hubungan pribadi antar dua orang sampai hubungan yang luas dalam sistem kenegaraan dan organisasi dunia. Dalam dialog antarpribadi, misalnya, mengapa seseorang sedikit melakukan pengambilan giliran (turn-taking), salah satu penyebabnya adalah persoalan kekuasaan.

Berita tentang demo buruh yang menuntut kenaikan upah dimuat di

http://lipsus.kompas.com/topikpilihanlist/1503/1/buruh.tuntut.kenaikan. upah "Demo Buruh, Dua Anggota LBH Dipukul dan Diseret Polisi" (31/10/2015). Kejadian bermula ketika polisi hendak membubarkan aksi massa. Tigor dan Obed, yang saat itu sedang bertugas mendampingi aksi buruh, juga ikut dipukul polisi ketika sedang menggunakan telepon genggamnya untuk mendokumentasikan aksi. Selain dipukul, oknum polisi juga menyeret keduanya ke dalam mobil, di samping itu ada 23 buruh ditangkap. Mereka ditangkap dengan brutal, diseret, dipukul hingga kepalanya robek.

Fenomena demo buruh tersebut merupakan sebagian realita kehidupan tentang dominasi kekuasaan yang "kebablasan." Pihak yang berkuasa dapat melakukan hal-hal di luar kontrol bahkan cenderung 
anarkhis dan sering merugikan pihak yang tertindas atau lemah. Dan bukan tidak mungkin kalau akhirnya menimbulkan suatu perlawanan atas kekerasan dan ketidakadilan yang muncul akibat dendam yang membara.

Karya sastra yang menempatkan bentuk protes dan perlawanan rakyat barangkali masih sangat sedikit. Ayu Utami dalam "Saman" dan "Larung" dapat dikatakan sebagai karya yang masih dapat menjaga tradisi keberpihakan pada rakyat bawah yang menuntut perubahan dengan gerakan untuk melawan penindasan Orde Baru (Soyomukti, 2012 :97).

Jika dipahami lebih lanjut, teks dalam novel Pasung Jiwa karya Okky Madasari banyak mengandung makna-makna perlawanan. Salah satu contohnya adalah pemakaian kata "hajar, demonstrasi, membalas, mengepalkan, menyerbu, menantang " adalah kosakata yang digunakan dalam novel tersebut. Semua kosakata yang menunjukkan perlawanan adalah representasi ideologi pengarang untuk melawan ketidakadilan dan penindasan.

Dapat disimpulkan bahwa kosakata "hajar, demonstrasi, membalas, mengepalkan, menyerbu, menantang" merupakan contoh kosakata yang di dalamnya mengandung makna perlawanan terhadap dominasi kekuasaan, baik kekuasaan individu, orang tua, masyarakat maupun pemerintah. Bentuk perlawanannya dapat dipahami secara langsung karena dalam novel Pasung Jiwa karya Okky Madasari tersebut disampaikan secara realistis.

Novel Pasung Jiwa sarat dengan nuansa perlawanan terhadap ketidakadilan, ketidakbebasan, dan kemanusiaan ini sangat baik untuk diapresiasi karena tema yang diangkat sangat relevan dengan keadaan Indonesia dewasa ini yang hingga kini masih banyak orang yang kehilangan kebebasan karena berbagai faktor seperti pandangan agama, sistem sosial, ekonomi, terlebih politik.

Dalam penelitian ini, akan dideskripsikan perlawanan yang tersembunyi dan terbuka dalam Novel Pasung Jiwa karya Okky Madasari. Sudut pandang yang digunakan adalah analisis wacana kritis. Dari sudut pandang analisis wacana kritis (Critical Discourse Analysis) yang lebih lanjut disingkat AWK, teks yang dianalisis dilihat sebagai wacana yang memiliki dan tidak dapat melepaskan diri dari konteksnya, baik berdasarkan aspek kebahasaan dalam struktur teks, proses interpretasi atas pemroduksian teks dan pengonsumsian teks, maupun berdasarkan praktik sosial politik (Vetter, 2000:154-155). Oleh karena itu, tujuan analisis wacana harus dilihat dari tiga dimensi secara simultan, yaitu teks-teks bahasa, praktik kewacanaan, dan praktik sosiokultural.

Perlawanan dalam penelitian ini adalah respon praksis dominasi yang diungkapkan secara halus dan tampak, yang di dalamnya menyembunyikan perlawanan terhadap praktik dominasi yang dapat dipahami melalui analisis kosakata, gramatika, struktur teks sebagai dimensi teks, konteks situasi dan makna ujaran sebagai dimensi praktik kewacanaan, dan sosiobudaya yang ada sebagai dimensi praktik sosiokultural.

Perlawanan merupakan segala tindakan yang dilakukan oleh kaum atau kelompok subordinat yang ditujukan untuk mengurangi atau menolak klaim yang dibuat oleh pihak atau kelompok superordinat terhadap mereka. Perlawanan merupakan bentuk dari pernyataan sikap 
yang dilakukan oleh masyarakat. Penyikapan masyarakat tersebut dalam bentuk perlawanan terhadap kelompok atau pihak yang dianggap mengancam eksistensi mereka selalu mengalami perubahan (Kusuma dan Agustina, ed., 2003). Hal ini tidak terlepas dari pengaruh isu yang diangkat dan mendapat dukungan dari masyarakat.

Perlawanan adalah sebuah antitesis, memilih untuk tidak tunduk pada produk budaya, gaya hidup, dan doktrin atau khotbah para penindas dan jongos-jongosnya (Soyomukti, 2012:13). Mungkin banyak orang yang apatis dengan berbagai aksi demontrasi yang dilakukan oleh rakyat, buruh, dan mahasiswa yang kian hari terjadi di mana-mana. Tetapi pada kenyataannya perlawanan rakyat kian hari kian meluas seiring dengan krisis ekonomi yang sampai sekarang ini belum selesai.

Berdasarkan pengertian perlawanan dapat disimpulkan bahwa perlawanan terhadap dominasi kekuasaan adalah semua tindakan yang terkuasai untuk melunakkan atau menolakkan tuntutan-tuntutan kelas itu yang dikenakan pada penguasa yang tampak dalam penggunaan bahasa. Atau dapat dikatakan sebagai respon praktik dominasi yang diungkapkan dalam penggunaan bahasa yang berbentuk lugas.

Zubir (2002) menyatakan bahwa perlawanan yang dilakukan oleh kelompok pinggiran (seperti buruh, pedagang, petani, dan lain-lain) bersifat sporadis. Dalam memperjuangkan keinginannya, gerakan ini tidak memiliki strategi perjuangan yang jelas sehingga lebih mudah untuk dipadamkan oleh pihak-pihak yang berkuasa. Apabila gerakan ini telah dimasuki oleh unsur ideologis, maka gerakan ini akan menjadi suatu gerakan yang radikal.

Sangaji (2000) membagi kedalam dua bentuk, yakni: (1) perlawanan yang diungkapkan secara individual, (2) perlawanan yang dilakukan melalui tindakan-tindakan kolektif atau bersama.

Kedua bentuk perlawanan tersebut diekspresikan dalam beragam cara, mulai dari aksi protes terbuka, yang diungkap melalui media massa, surat protes, pengiriman delegasi, atau melalui kesempatan dialog, seminar, hingga cara-cara tertutup, seperti aksi tutup mulut dan tidak menghadiri pertemuan dengan rival. Di samping itu, perlawanan yang dilakukan oleh kelompok pinggiran ini juga mendapat dukungan dari organisasi atau individu yang umumnya berasal dari kalangan terpelajar, seperti mahasiswa, tokoh intelektual setempat (Sangaji, 2000).

Sedangkan Scoot (2000) membagi dua bentuk perlawanan yangterdiri atas perlawanan publik atau terbuka (public transcript) dan perlawanan tersembunyiatau tertutup (hidden transcript).

Bentuk perlawanan terbuka yaitu perlawanan yang mudah terjadi dalam suatu lingkungan atau masyarakat tertentu yang berpotensi untuk melakukan suatu gerakan massa secara spontan dan berkesinambungan (seperti lingkungan kampus, buruh, petani, dan sebagainya). Perlawanan ini akibat adanya tekanan-tekanan struktural (structural strain) yang akan mempercepat orang untuk melakukan gerakan massa secara spontan karena keinginan mereka untuk melepaskan diri dari situasi yang menyengsarakan.

Perlawanan terbuka atau publik dapat dicirikan sebagai perlawanan yang bersifat: 1) organik, sistemik, dan kooperatif, 2) berprinsip atau tidak mementingkan diri sendiri, 3) berkonsentrasi revolusioner, dan 4) mencakup gagasan/ maksud meniadakan basis dominasi. 
Perlawanan tertutup atau disebut juga perlawanan sembunyisembunyi dapat dicirikan sebagai perlawanan yang bersifat: (1) tidak teratur, tidak sistematik dan terjadi secara individual, (2) bersifat oportunistik dan mementingkan diri sendiri, (3) tidak berkonsekuensi revolusioner, dan/atau (4) lebih akomodatif terhadap sistem dominasi. Oleh karena itu, gejala-gejala kejahatan seperti: pencurian kecil- kecilan, hujatan, makian, bahkan pura-pura patuh (tetapi di belakang membangkang) merupakan perwujudan dari perlawanan sembunyi-sembunyi.

Ada dua faktor penyebab munculnya perlawanan atau disebut sebagai tindakan (Sukidin, 2003: 236) yaitu faktor internal masyarakat atau individu sendiri dan faktor eksternal dari si pelaku. Faktor internal berasal dari dalam diri manusia yaitu dalam kedudukannya sebagai individu yang mempunyai pengaruh dalam masyarakat. Untuk faktor internal ini dibedakan dalam dua jenis, yaitu pertama, naluri jahat yang dimiliki manusia, tetapi kadar naluri setiap manusia tidak sama. Kedua, kekuatan introspeksionisme yaitu kekuatan yang mendorong manusia memperoleh dan memenuhi kebutuhannya.

Sedangkan faktor eksternal adalah faktor yang berasal dari luar diri manusia yang memengaruhi tindak dan perilaku masyarakat untuk melakukan kekerasan. Faktor ini antara lain, pertama, eksistensi hukum yang terkait dengan kepercayaan masyarakat terhadap institusi hukum. Kedua, respon pasif masyarakat dalam kebijakan publik, karena selama ini rasa takut hanya ada dalam diri masyarakat jika terlibat dalam ranah kebijakan publik. Ketiga, tingkat heterogenitas sosial yang sangat tinggi, dengan berbagai karakter yang muncul dalam diri masyarakat menyebabkan individu bergerak mengikuti arus kekuatan masyarakat. Keempat, faktor ekonomi, kondisi ekonomi negara yang yang tidak menentu memengaruhi kondisi ekonomi masyarakat dan inilah yang menjadi pemicu munculnya tindak kekerasan dan kelima, perubahan kondisi politik bangsa, dengan bergantinya kepemimpinan suatu bangsa kebijakan yang diambil kadang-kadang tidak sesuai dengan aspirasi dan kehendak rakyat ini pun memicu tindakan anarkis masyarakat.

Menganalisis wacana secara kritis pada hakikatnya adalah menganalisis tiga dimensi wacana secara integral. Menurut Jorgensen dan Philips (2007: 128) model tiga dimensi Fairclough ini merupakan kerangka analisis yang digunakan untuk penelitian empiris tentang komunikasi dan masyarakat. Analisis tersebut hendaknya dipusatkan pada (1) ciri-ciri linguistik teks tersebut, (2) proses yang berhubungan dengan pemroduksian dan pengorganisasian teks itu (praksis kewacanaan), dan (3) praksis sosial yang lebih luas yaitu mencakup peristiwa komunikatif (praksis sosial).

Analisis wacana kritis banyak memanfaatkan piranti linguistik yang disarankan dalam linguistik fungsional sistemik Halliday (1985:1994) dan linguistik kritis Fowler (1986)untuk memberikan kepemilikan struktur linguistik dalam teks bahasa (Santoso, 2009:5).

Praksis kewacanaan berkaitan dengan produksi dan interpretasi proses-proses diskursif (Santoso, 2006:67). Praksis wacana bisa jadi menampilkan ideologi, dapat memproduksi dan mereproduksi hubungan kekuasaan yang tidak berimbang antara kelas sosial, laki-laki dan perempuan, kelompok mayoritas, dan minoritas (Badara, 2012:28-29). Kedua pernyataan tersebut berarti perlawanan terbuka dan tertutup 
dalam novel Pasung Jiwa merupakan representasi ideologi sebagai praksis kewacanaan institusi kekuasaan yang tidak berimbang antara kelas sosial dalam masyarakat.

Dimensi praktik sosiokultural sebagai analisis tahap ketiga dalam AWK ini berupa tahap menjelaskan relasi fitur-fitur tekstual yang heterogen berupa kompleksitas proses wacana dengan perubahan sosiokultural, baik perubahan masyarakat, institusional, maupun kultural (Santoso, 2009: 56). Hubungan teks dan konteks dalam karya sastra memiliki relevansi khusus dalam konsep wacana sebagai praksis sosiokultural.

Dalam hal ini, posisi ideologis secara eksplisit yang menjadi fokus kajian/penelitian. Pernyataan tersebut diartikan bahwa novel Pasung Jiwa karya Okky Madasari merupakan wadah wacana sebagai praksis sosiokultural.

Berdasarkan uraian tentang dimensi praksis sosiokultural tersebut maka analisis praksis sosiokultural adalah menghubungkan teks dan struktur sosial dimediasikan dengan konteks sosial wacana. Analisis tahap ketiga AWK ini berupa tahap menjelaskan relasi fitur-fitur tekstual yang heterogen beserta kompleksitas proses wacana dengan proses perubahan sosiokultural, baik perubahan masyarakat, institusional, maupun kultural.

Jenis penelitian yang digunakan dalam penelitian ini adalah kualitatif deskriptif artinya data yang dianalisis dan hasil analisisnya berbentuk deskripsi fenomena, tidak berupa angka-angka koefisien tentang hubungan antar-variabel. Tulisan hasil penelitian berisi kutipankutipan dari kumpulan data untuk memberikan ilustrasi dan menjadi materi laporan (Aminnudin, 1990:16).

Dalam hal ini, akan diungkapkan data-data berupa uraian-uraian dan percakapan-percakapan yang ada dalam novel Pasung Jiwa. Selain itu juga permasalahan-permasalahannya dianalisis dengan teori analisis yang digunakan yaitu teori kekuasaan Bourdeau dan teori analisis wacana kritis (AWK). Hal-hal yang perlu dipaparkan dalam penelitian ini meliputi objek penelitian, sumber data, teknik pengumpulan data, dan teknik analisis data.

Data penelitian ini berupa kata-kata, kalimat, dan wacana (Ratna, 2004 : 6) yang berkaitan dengan perlawanan terbuka dan tertutup dalam novel Pasung Jiwa karya Okky Madasari.Novel ini diterbitkan kepustakaan populer Gramedia, cetakan ke-1 Mei 2013, dengan tebal 328 halaman.

Metode pengumpulan data yang digunakan dalam penelitian ini adalah metode pustaka atau dokumentasi. Berarti peneliti melakukan pencatatan secara cermat, terarah, dan teliti terhadap sumber data, yakni teks novel Pasung Jiwa untuk memperoleh data yang diinginkan.Teknik analisis data yang digunakan dalam penelitian ini adalah model interaktif dari Miles dan Hubberman. Dalam analisis interaktif, data yang diperoleh dari lapangan akan mengalami reduksi data. Hal ini dilakukan untuk menemukan fokus penelitian. Menurut Miles dan Hubberman (Sugiyono, 2012: 247) bahwa dengan menggunakan analisis model interaktif dilakukan melalui tiga prosedur, yaitu: reduksi data, penyajian data, dan penarikan simpulan (verifikasi). 
Dalam subbab ini, peneliti menganalisis perlawanan terbuka dan tertutup dalam novel Pasung Jiwa karya Okky Madasari. Perlawanan terbuka dan tertutup dalam penelitian ini difokuskan pada analisis wacana kritis yang meliputi dimensi (1) struktur teks (2) praksis wacana, dan (3) praksis sosiokultural.

\section{Bentuk Perlawanan Terbuka}

Bentuk perlawanan terbuka digambarkan dalam novel Pasung Jiwa karya Okky Madasari, diawali dari masyarakat yang merasa tertindas dengan ulah para pejabat yang serakah dan tidak benar dalam mengurus pemerintahan. Sehingga masyarakat ingin berjuang melawan pejabat yang tidak bisa mengatur pemerintahan dengan dengan benar.

"Kita korban.Korban pemerintahan yang ndak bener. Korban pejabat yang serakah," kata yang lainnya lagi.

"Kita harus melawan. Jangan diam saja kalau sudah bisa makan," kata mereka lagi.

"Kita kerja keras cukup buat makan. Sementara di sana banyak orang tinggal ongkang-ongkang duitnya miliaran," kata yang lainnya. (PJ/BPTb/OM/2013/66)

Melihat percakapan di atas menunjukkan sekelompok orang tersebut ingin berjuang mengadakan perlawanan terhadap pejabat pemerintah yang tidak bisa mengatur pemerintahan demi kesejahteraan rakyatnya melainkan hanya mementingkan pribadinya. Ini nyanyian masyarakat yang merasa tertindas.

Kami rakyat jelata

Peras keringat untuk makan

Kalian pejabat Negara

Rampok sini, rampok sana

Rakyat tak lagi sabar

Semuanya sudah lapar

Beri kami keadilan

Atau kami turun ke jalan

Ayo semua yang lapar

Jangan lagi hanya diam

Tanah ini milik kita

Negeri ini kita yang punya (PJ/BPTb/OM/2013/67-68).

Perlawanan yang lain juga terjadi pada peristiwa hilangnya Marsini putri Cak Man, pemilik warung kopi tempat Sasa bertemu Cak Jek. Marsini menghilang setelah menuntut kenaikan upah di pabrik sepatu tempatnya bekerja di Sidoarjo.

Lima orang termasuk Marsini, menghadap mandor agar menyampaikan permintaan itu ke atasan. Karena tak digubris mereka nekat menghadap bagian personalia. Lima orang ini berani melakukan hal itu, karena kenaikan upah yang mereka minta hanya mengikuti peraturan baru yang sah. Pertemuan dengan kepala personalia tetap tak membuahkan hasil. Lima 
orang ini membagikan selebaran ke semua buruh. Mengajak mogok sampai ada kenaikan upah. (PJ/BPTb/OM/2013/ 83).

\section{Bentuk Perlawanan Tertutup \\ a. Perlawanan yang dilakukan tokoh Sasana}

Perlawanan tokoh Sasana terhadap orang tuanya, ia seorang anak laki-laki kebanggaan orang tuanya, musik piano dan klasik yang disinyalir dapat memberikan kecerdasan kepada anak-anaknya dan hal itu dibuktikan dengan memaksa Sasana bermain piano sampai akhirnya meraih beberapa penghargaan. Namun hati kecil Sasana berontak dan tidak menyukai piano.

Akulah anak kesayangan dan kebanggaan. Anak pertama, lakilaki satu-satunya. Hingga kemudian aku berulah. (PJ/BPTt/OM/2013/17)

Perlawanan tokoh Sasana terhadap perangkap tubuhnya, ia seorang laki-laki tetapi lebih menyukai berpenampilan perempuan tetapi ia tidak berani melakukannya karena secara sosial kelompok transgender masih belum mendapat pengakuan sebagai gender, yang ada gender lakilaki atau perempuan.

Aku benci perkelahian, aku tak mau ada darah. Aku benci dunia laki-laki. Aku ingin tenggelam dalam dunia Melati. (PJ/BPTt/OM/2013/39)

Akhirnya Sasana melakukan perlawanan terhadap perangkap tubuhnya dengan mengorbankan semua yang menjadi harapan orang tuanya. Sasana rela meninggalkan kuliahnya demi mencari kenyamanan dalam hidupnya. Sasana mengubah namanya menjadi Sasa. Ia menikmati perubahan penampilan dirinya dari seorang pria menjadi wanita seksi dengan goyangan mautnya. Dengan menjadi Sasa ia merasa nyaman dan bebas menjadi apa yang dia inginkan.

Hidupku kini hanya untuk berdendang dan bergoyang.Sudah tak terhitung berapa kali aku membolos kuliah. Aku malah sudah lupa bahwa aku berada di kota ini untuk kuliah. Kiriman orangtua tetap datang tiap bulan. (PJ/BPTt/OM/2013/49).

\section{b. Perlawanan yang dilakukan tokoh Cak Jek (Jaka Wani)}

Cak Jek di saat bekerja di pabrik elektronik di Batam mendapat perlakuan yang tidak adil, pada saat dia tidak sengaja memecahkan kaca di perusahaan itu dia harus mengganti kaca yang dipecahkan dengan harga yang tinggi. Padahal Cak Jek sudah lama bekerja di perusahaan itu, bahkan ini peristiwa kali pertama selama ia bekerja di perusahaan tersebut. Maka terjadilah perlawanan Cak Jek terhadap mandor pabrik yang tidak adil dalam bertindak.

Mandor masih tetap menuntut Cak Jek untuk mengganti barang itu. Akhirnya Cak Jek marah melawan mandor tersebut. 
Bangsat! Ini bukan sekadar soal upah dua hari. Ini soal harga diri. Aku tidak sudi tenagaku diperas tanpa mendapat upah yang memang sudah jadi hakku. (PJ/BPTt/OM/2013/197-198)

Cak Jek tetap mempertahankan harga dirinya, dia tidak mau upahnya dipotong untuk mengganti kaca pecahkannya itu karena bukan kesengajaan melainkan kecelakaan kerja.

"Tapi sekarang saya disuruh kerja dua hari tanpa upah?"

"Hanya dua hari. Kamu seharusnya tidak di upah lima hari."

"Saya tidak mau!" kataku tegas dan keras. Entah setan mana yang sudah merasukiku. Aku sudah tak lagi punya rasa takut. Aku memang tidak bisa membela Elis, tidak bisa membela dua buruh yang dipecat itu, tapi aku harus membela diriku sendiri. (PJ/BPTt/OM/2013/198).

\section{c. Perlawanan yang dilakukan tokoh Elis}

Perlawanan tokoh Elis terhadap suaminya, dia lebih memilih menjadi pelacur kelas bawah daripada hidup terkungkung bersama suaminya. Suaminya tidak lagi bertanggung jawab akan kelangsungan hidup keluarganya, lebih mementingkan kesenangan hidupnya sendiri yang suka bermain dengan wanita lain. Sehingga Elis ingin membebaskan dirinya dari kungkungan itu.

"Yang penting anak saya tidak kurang uang. Yang penting tidak hidup sama bapaknya yang bajingan. Terus yang penting saya bisasenang. Bisa merdeka.Cuma itu kan yang penting?" (PJ/BPTt/OM/2013/172)

Selanjutnya perlawanan Elis terhadap pelanggan yang menuduh dirinya sebagai pencuri mengambil uangnya, padahal sesungguhnya itu adalah bayaran Elis selama diajak kencan. Hal ini berawal dari ketidakmauan Elis diajak kencan tanpa menggunakan kondom, sehingga pelanggan itu marah-marah dengan menarik rambut Elis hingga kepalanya dekat ke mulut laki-laki itu. Begitu juga dengan bos pemilik tempat itu tidak menyelesaikan perkaranya dengan baik, malahan dia mengusir Elis dari tempat tersebut. Di sinilah muncul perlawanan Elis dengan meludai wajah tamunya dan wajah bos penilik tempat itu.

"Kamu Lis! Pergi dari tempat ini sekarang juga. Bawa semua barangmu!"

Cuh! Ludah Elis meloncat ke wajah tamunya dan ke wajah bos tempat ini. ... (PJ/BPTt/OM/2013/180)

Elis adalah sosok pelacur yang melayani para buruh pabrik dengan bayaran rendah. Menjadi pelacur katanya bukan karena paksaan, melainkan suatu pilihan, daripada hidup dengan suami yang bajingan. Jika orang pintar bekerja dengan otaknya, dan buruh bekerja dengan tenaganya, maka ia memilih bekerja dengan organ kewanitaan yang ia punya. 


\section{d. Perlawanan yang dilakukan tokoh Kalina}

Kalina berontak dan meronta di hadapan buruh pabrik. Ia protes dipecat karena ia hamil, sementara yang menghamilinya adalah mandor sendiri. Nasibnya hampir sama dengan buruh perempuan lain yang dipaksa melayani permintaan para mandor tanpa bisa mengelak. Kalina melakukan perlawanan kepada mandor yang telah menghamili dan memecatnya untuk menuntut haknya.

Tidak ada tanggapan yang baik dari mandor akhirnya Kalina semakin berontak dengan perlakuan mandor tersebut.

"Saya bongkar semuanya sekarang! Biar semua orang di sini tahu!" Kini perempuan itu lari ke tengah ruangan, berdiri di meja terdepan.

"Mandor itu ... Mandor itu sudah memperkosa saya!" Perempuan itu bicara sambil menuding ke arah si mandor. Si mandor bergerak, menarik tangan perempuan itu tak bisa dibendung lagi. "Sekarang saya bunting, saya malah dipecat! Dasar binatang! Dia perkosa saya juga seperti binatang!" (PJ/BPTt/OM/2013/195)

\section{e. Perlawanan yang dilakukan tokoh Sarti}

"Kita kan sudah pernah melawan. Tetap saja kita dipecat. Tetap saja tidak ada yang peduli," kata Sarti (PJ/BPTt/OM/2013/210)

Lewat kelimatokohnya, Okky menyiratkan keberanian untuk menguak rasa takut. Melawan, itulah kata-kata yang tepat. Tapi sejauhjauhnya mereka melawan diri sendiri dan juga apa yang ada di sekitar, lagi-lagi mereka terperangkap. Mereka tak sepenuhnya bebas. Atau memang sebenarnya tidak ada kebebasan yang mutlak.

\section{Tahap-Tahap Analisis Wacana Kritis (Dimensi Teks Wacana)}

\section{a. Kosakata melalui Nilai Pengalaman}

Dalam kajian kosakata sebagai nilai pengalaman ini, kata-kata tertentu diperjuangkan melalui suatu pertarungan ideologis. Dalam teks, sering muncul kata-kata tertentu yang dominan, selalu muncul dan dinaturalisasikan kepada pembaca. Kata-kata tersebut selalu diulangulang dalam berbagai peristiwa tutur, yaitu kata "melawan" yang dapat dilihat pada kutipan-kutipan berikut ini.

"Betul! Kita harus melawan."

"Yang Seperti ini tak boleh dibiarkan."

"Buruh selalu ditindas."

"Kita akan ikut aksi itu. Semakin banyak orang semakin baik." (PJ/ KNP /OM/2013/90)

Kosa kata dengan nilai pengalaman yang lain yaitu relasi makna yang meliputi sinonim, antonim, dan hiponim. Sebagian relasi makna yang terdapat dalam novel Pasung Jiwa karya Okky Madasari ini adalah sinonim kata "melawan dan membalas" seperti terlihat pada kutipan berikut ini. 
"Kita harus melawan, kita harus membalasnya," teriakku keras sambil mengepalkan tangan ke atas. ( PJ/ KNP /OM/2013/126)

Relasi makna yang lain adalah hiponim yang memiliki dimensi ideologis tertentu. Seperti kata "disekap, disiksa, dan diperkosa."

Ini bagian dari persiapanku untuk menyerbu markas tentaratentara itu. Tempat aku dikurung lalu disiksa dan diperkosa. Aku yakin mereka jugalah yang telah membunuh Marsini. Tentaratentara itu sudah jadi anjing peliharaan pemilik pabrik. Mereka menggonggong dan menggigit siapa saja yang hendak mengganggu tuannya, termasuk marsini. Pasti sebelum dibunuh Marsini juga disekap, disiksa, dan diperkosa seperti aku. (PJ/KNP/OM/2013/126)

\section{b. Kosakata melalui Nilai Relasional}

Ada tiga hal yang berkaitan dengan nilai relasional yaitu 1) ekspresi eufemistik, 2) pilihan kata-kata "formal", dan 3) pilihan katakata "informal." Dalam novel Pasung Jiwa karya Okky Madasari, ekspresi eufemistik tidak muncul karena perlawanan dalam novel ini bukan perlawanan simbolik tetapi realistis. Pada pilihan kata formal yaitu terdapat kosakata ilmiah seperti "demonstrasi dan profesional." Pilihan kata yang formal ini akan menciptakan kesan kekuasaan, posisi, dan status.

"Kita bikin demonstrasi!" jawab Cak Jek. "Tapi demonstrasi cara kita. Kamu nyanyi dan goyang, aku sama-sama bocah-bocah main musik seperti biasa.

(PJ/ KNR/OM/2013/88)

Sedangkan pilihan kata yang informal ditunjukkan melalui pilihan kata yang sangat mudah dipahami oleh pendengarnya. Kata informal sering dipilih untuk menciptakan aspek-aspek solidaritasn kesantunan dan ekspresi afektif.

"Ya aku hajar semuanya. Memang aku takut apa?"

"Kon iki yo.... mbok rodo mikir....

Memangnya mampu melawan orang segitu banyak?"

(PJ/KNR/OM/2013/63)

\section{c. Kosaka melalui Nilai ekspresif}

Dua hal yang berkaitan dengan nilai ekspresif adalah "evaluasi positif" dan "negatif." Penutur sering memunculkan evaluasinya terhadap realitas secara implisit maupun eksplisit melalui kosakata ini. Tetapi dalam novel Pasung Jiwa disebutkan evaluasi muncul secara eksplisit. Okky Madasari melakukan evaluasi negatif melalui tuturan kata "sampeyan" terhadap realitas sosial tentang protes tokoh Marjinal yang protes terhadap ketidakberesan pemerintah yang tidak peduli terhadap rakyat jelata.

"Yok opo, Cak? Kalau sampeyan saja tak mau peduli, siapa lagi yang akan peduli dengan nasib kita ini?" 
"Yang penting buat kami bisa tetap makan tiap hari, terus hati senang terus. Gak onok urusan karo negoro, gak onok urusan karo politik-politikan.” Jawab Cak Jek.

"Sampeyan mungkin memang tidak ada urusan sama negara. Tapi negara punya urusan sama sampeyan." (PJ/KNE/OM/2013/67)

Penilaian negatif terhadap permasalahan sosial juga disampaikan Okky Madasari melalui tuturan "saya" yang berpendapat tentang ketidakadilan dan kesewenang-wenangan para pemilik modal dalam hal ini pemilik pabrik atau perusahaan terhadap anak buah atau karyawannya.

"Tapi sekarang saya disuruh kerja dua hari tanpa upah?"

"Hanya dua hari. Kamu seharusnya tidak di upah lima hari."

"Saya tidak mau!" kataku tegas dan keras. Entah setan mana yang sudah merasukiku. Aku sudah tak lagi punya rasa takut. Aku memang tidak bisa membela Elis, tidak bisa membela dua buruh yang dipecat itu, tapi aku harus membela diriku sendiri. (PJ/KNE/OM/2013/198)

Selain evaluasi negatif, penulis juga melakukan penilaian positif terhadap permasalahan sosial yang terjadi di masyarakat, misalnya praktik "pelacuran" di rumah-rumah bordir. Dengan bergaya tutur "saya" penulis juga berkomunikasi dengan tokoh yang lain, misalnya pelanggan yang ingin melaporkan tempat "maksiat" tersebut menjadi yang agamis.

"Akan saya laporkan tempat ini ke polisi," kata laki-laki itu. Seorang laki-laki tua keturunan Cina datang. "Ada apa ini?" tanyanya sambil menepuk pundak laki-laki pelanggan itu.

Laki-laki Cina itu pemilik tempat ini. (PJ/KNE/OM/2013/179)

\section{d. Gramatika melalui Nilai Pengalaman}

Pada tahap nilai pengalaman terdapat empat aspek yang dikaji dalam kepemilikan nilai pengalaman gramatika yaitu (1) ketransitifan, (2) nominalisasi, (3) kalimat aktif-pasif, dan (4) kalimat positif-negatif.

Data yang menunjukkan adanya nilai pengalaman dari aspek ketransitifan (kalimat transitif) yaitu mengandung perlawanan terhadap petugas yang berusaha menghalau para penghuni rumah sakit tersebut.

Kami semua menantang petugas itu. Tongkat-tongkat yang tadi aku bagikan di dalam kamar kini digunakan seperti yang seharusnya. (PJ/GNP/OM/2013/155)

Sedangkan nilai pengalaman yang mencakup aspek nominalisasi yaitu perlawanan yang dilakukan oleh Sasana terhadap laki-laki yang berani kurang ajar dan tidak senonoh itu. Sasana akhirnya terpaksa melawan dengan cara memukul dan menendang dada serta kemaluan laki-laki tersebut.

Tak ada lagi sisa kelembutan dalam diriku.Semuanya hanya kemarahan dan kebuasan. Orang seperti ini harus dimusnahkan. 
Orang seperti ini jangan dibiarkan. Sudah tak pantas lagi disebut manusia jika sudah tak bisa lagi melihat orang lain sebagai manusia. (PJ/GNP/OM/2013/62)

Nilai pengalaman yang meliputi aspek kalimat aktif dan pasif dapat terlihat pada data "Kita pancing...." menunjukkan aspek kalimat pasif yang mencerminkan perlawanan untuk menarik perhatian masyarakat terhadap ketidakberesan dan ketidakadilan dalam pabrik tersebut.

"Gini," jawab Cak Jek dengan serius." Kita pancing perhatian semua orang. Kita buat agar terpaksa semua orang melihat kita dan mendengar apa yang kita katakan.” (PJ/GNP/OM/2013/88)

Nilai pengalaman yang menyangkut aspek kalimat aktif seperti terlihat pada data "Ia menolak...." yang mencerminkan perlawanan Banua terhadap orang tuanya yang telah memaksanya untuk masuk ke pesantren.

Banua memulai ceritanya ketika ia dipaksa masuk ke pesantren setelah lulus SMP. Ia menolak, tapi orangtuanya tetap memaksa. Aku bisa paham ketidakberdayaannya. Aku dulu juga demikian. Apa yang bisa dilakukan bocah untuk melawan orangtuanya? (PJ/GNP/OM/2013/140)

Data perlawanan nilai pengalaman yang merupakan aspek kalimat positif terlihat pada kutipan "Ia menolak".

Banua memulai ceritanya ketika ia dipaksa masuk ke pesantren setelah lulus SMP. Ia menolak, tapi orangtuanya tetap memaksa. Aku bisa paham ketidakberdayaannya. Aku dulu juga demikian. Apa yang bisa dilakukan bocah untuk melawan orangtuanya? (PJ/GNP/OM/2013/140)

Pada data berikutnya merupakan perlawanan yang menunjukkan kalimat negatif "Saya tidak mau .....". Cak Jek dengan tegas menolak keputusan supervisor itu bahkan dia sempat menjotos muka si supervisor sampe akhirnya dia keluar dari pabrik tersebut.

"Tapi sekarang saya disuruh kerja dua hari tanpa upah?"

"Hanya dua hari. Kamu seharusnya tidak di upah lima hari."

"Saya tidak mau!" kataku tegas dan keras. Entah setan mana yang sudah merasukiku.Aku sudah tak lagi punya rasa takut. Aku memang tidak bisa membela Elis, tidak bisa membela dua buruh yang dipecat itu, tapi aku harus membela diriku sendiri. (PJ/GNP/OM/2013/198)

\section{e. Gramatika melalui Nilai Relasional}

Kajian gramatika pada penelitian ini antara lain mencakup kajian pada aspek nilai relasional. Nilai relasional ini berhubungan dengan cara gramatika mengodekan isyarat relasi hubungan sosial timbal balik yang diperankan penghasil teks. Salah satu aspek yang dikaji dalam nilai 
relasional ini adalah modalitas. Modalitas relasional terdiri dari (1) intensional, (2) epistemik, (3) deontik, dan (4) dinamik (Alwi dalam Santoso (2003: 59).

Data yang menunjukkan modus kalimat dalam bentuk 'kalimat tanya' yang merupakan makna perlawanan terhadap sekelompok preman yang berusaha mengganggu tokoh Sasana dan Cak Jek ketika mereka sedang mengamen di alun-alun.

"Ya aku hajar semuanya.Memang aku takut apa?"

"Kon iki yo.... mbok rodo mikir....

Memangnya mampu melawan orang segitu banyak?"

(PJ/GNR/OM/2013/63).

Kalimat deklaratif ditemukan pada perlawanan para penghuni rumah sakit jiwa yang diajak kabur oleh Sasana atas bantuan Dokter Masita.

Kami sетиа menantang petugas itu. Tongkat-tongkat yang tadi aku bagikan di dalam kamar kini digunakan seperti yang seharusnya.

(PJ/GNR/OM/2013/155).

Dan kalimat imperatif (perintah) dapat terlihat pada data yang merupakan perintah dari Sasana untuk membalas dendam atas kematian Marsini yang tidak wajar.

“Balaskan dendam Marsini! Balaskan dendamku!” teriakku. Masih sambil terus mengacungkan parang dan bergerak mengelilingi ruangan. Orang-orang menyingkir ketakutan. (PJ/GNR/OM/2013/126)

Kalimat pada data yang menggunakan modalitas intensional yaitu "ayo semua yang lapar." Ajakan pengarang untuk mengikuti ideologi yang diperjuangkan yaitu mengajak rakyat yang kelaparan untuk melawan penindasan. Pada data lain juga menunjukkan modalitas deontik yaitu pada kalimat "Jangan lagi hanya diam."

Rakyat tak lagi sabar

Semuanya sudah lapar

Beri kami keadilan

Atau kami turun ke jalan

Ayo semua yang lapar

Jangan lagi hanya diam

(PJ/GNR/OM/2013/67-68)

Pada data kalimat "Aku ingin bebas sekarang" dapat terlihat tentang modalitas deontik yang menyuarakan keinginan pengarang tentang sebuah kebebasan.

Aku ingin bebas sekarang. Aku tak mau terkungkung, terpenjara. Tidak untuk sepuluh tahun, setahun, atau sehari sekalipun. Aku 
tak sudi menyerahkan sedetik pun hidupku. Aku mau bebas sekarang juga. (PJ/GNR/OM/2013/306)

Pronomina persona atau partisipan untuk menyatakan sikapnya, penulis menggunakan agen pelaku yang jelas. Agen pelaku yang jelas itu adalah menggunakan pelaku "saya", yaitu penulis sendiri. Hal ini dilakukan bahwa sikap penulis tidak perlu disembunyikan. Ini bisa dimengerti karena sampai saat ini keadilan belum ditegakkan.

"Tapi sekarang saya disuruh kerja dua hari tanpa upah?"

"Hanya dua hari. Kamu seharusnya tidak di upah lima hari."

"Saya tidak mau!" kataku tegas dan keras. Entah setan mana yang sudah merasukiku. Aku sudah tak lagi punya rasa takut. Aku memang tidak bisa membela Elis, tidak bisa membela dua buruh yang dipecat itu, tapi aku harus membela diriku sendiri. (PJ/GNR/OM/2013/198)

Modalitas epistemik dapat dilihat pada data "harus", yaitu ideologi penguatan yang digunakan dan diperjuangkan pengarang untuk selalu melawan ketidakadilan dan kesewenang-wenangan.

"Kita kerja keras cukup buat makan. Sementara di sana banyak orang tinggal ongkang-ongkang duitnya miliaran," kata yang lainnya.

“Kita harus melawan, kita harus membalasnya,"teriakku keras sambil mengepalkan tangan ke atas. (PJ/GNR/OM/2013/ 126)

\section{f. Gramatika melalui Nilai Ekspresif}

Gramatika yang bernilai ekspresif ditunjukkan oleh modalitas ekspresif. Modalitas menjadi ekspresif apabila modalitas adalah persoalan otoritas penutur atau penulis yang berkenaan dengan kebenaran atau kemungkinan representasi realitas. Penggunaan tindak ekspresif bisa berkaitan dengan rasa senang dan tidak senang atau bisa juga disebut sebagai sikap positif dan negatif kekuasaan penulis terhadap realitas sosial yang terjadi dalam masyarakat. Data berikut merupakan sikap tidak senang penulis terhadap kesewenang-wenangan pemerintah yang tidak peduli terhadap rakyat jelata.

Kini mereka berjalan menuju ke arah kami.

"Kita pakai rencana kita," kata Cak Jek begitu sampai di tempat kami.

"Tunggu jam dua belas," kata salah satu kawan Marjinal. Kamimerencakan aksi jam dua belas karena itu saat istirahat pekerja. Dengan begitu akan banyak orang yang menyaksikan aksi ini.

(PJ/GNE /OM/2013/91)

Sikap negatif penulis juga ditunjukkan pada data tentang rasaketidaksenangan tokoh Sasana terhadap sikap preman yang berbuat kurang ajar terhadapnya dengan merampas hasil keringatnya dari mengamen. 
Aku cari uang dengan menukar tenaga dan keahlianku. Menyerah pada tukang peras sama saja dengan menghina orang yang sudah kerja keras. Aku tendang kemaluan orang di depanku. Ia berteriak kesakitan, tapi tak lama kemudian pukulannya mendarat di kepalaku. (PJ/ GNE /OM/2013/236)

\section{g. Struktur Teks}

Kajian struktur teks dalam penelitian ini menyangkut kajian gilir tutur dan pengontrolan partisipan. Dalam gilir tutur yang partisipannya tidak sejajar, gilir tutur juga akan tidak sejajar. Demikian juga untuk pengontrolan partisipan, pada partisipan yang memiliki kekuasaan besar akan memaksakan kontribusinya pada partisipan yang kekuasaannya lebih kecil. Hasil analisis struktur teks novel Pasung Jiwa karya Okky Madasari adalah sebagai berikut. Dalam novel Pasung Jiwa karya Okky Madasari terdapat komunikasi satu arah. Komunikasi satu arah ini artinya tidak terdapat gilirtutur. Partisipan yang digunakan adalah "kita" yang mewakili suara hati rakyat yang tertindas atas ketidakberesan pemerintahan.

"Bener. Negara kita ini sudah bubrah. Lha pemerintahnya saja bromocorah," sahut salah satu dari mereka.

"Kita ini korban. Korban pemerintah yang ndak bener. Korban pejabat yang serakah," kata yang lainnya lagi.

Aku dan Cak Jek hanya diam. Kami sama-sama bingung.

"Kita harus melawan. Jangan diam saja kalau sudah bisa makan," kata mereka lagi. Pandangannya serius menatap kami. (PJ/ST/OM/2013/66)

Bentuk komunikasi yang lain adalah komunikasi dua arah dan terdapat interupsi. Okky menggunakan kata penanda interupsi menimpal, nyeletuk, potong, timpas, sanggahan, membantah, nyelonong, sik-sik, hush, hah.

Pada data kutipan berikut terdapat interupsi saat Ayah berbicara ditimpali oleh Ibu yang merasa jengkel atas ketidakadilan pejabat yang tidak mau menegakkan hukum secara benar. Gilir tutur antara ayah dan ibu tersebut menunjukkan adanya kelas sosial yang seimbang antara Ayah dengan Ibu. Tidak terdapat kesenjangan sosial dan tidak ada yang berkuasa dan dikuasai.

"Ada satu anak jenderal, satu anak pejabat. Kasusnya tidak bisa diproses," jawab Ayah datar.

"Hah? Anak kita disiksa seperti anjing lalu pelakunya tidak bisa diproses?" Ibu berteriak. Kini ia bukan hanya marah pada orangorang yang menganiayaku dan pada polisi yang tak memproses perkaraku. Ia marah pada ayahku. (PJ/ST/OM/2013/42)

\section{Tahap-Tahap Analisis Wacana Kritis (Dimensi Praksis Kewacanaan) \\ a. Konteks situasi \\ Dalam Pasung Jiwa karya Okky Madasari terdapat konteks situasi yang melatarbelakangi adanya. Konteks situasi tersebut merupakan praktik diskursif yangakan memberikan pengaruh dan menentukan cara}


teks diproduksi. Bagaimana teks tersebut diproduksi dapat diamati melalui konteks situasi apa yang melatarbelakangi adanya wacana tersebut. Konteks situasi tersebut baik yang ada di dalam maupun di luar teks. Yang demikian dapat diamati melalui konteks situasi sebagaimana data berikut ini.

Pada data berikut, perlawanan terjadi karena konteks situasi pada produksi teks tersebut ketika sedang ngamen di alun-alun kota Batu, Sasana dan Cak jek diganggu oleh segerombolan preman yang berani berbuat kurang ajar terhadap Sasana.

Tak ada lagi sisa kelembutan dalam diriku. Semuanya hanya kemarahan dan kebuasan. Orang seperti ini harus dimusnahkan. Orang seperti ini jangan dibiarkan. Sudah tak pantas lagi disebut manusia jika sudah tak bisa lagi melihat orang lain sebagai manusia. (PJ/KS/OM/2013/62)

Sedangkan pada data lain, konteks situasi yang terjadi pada waktu itu yaitu ketidakberesan dan ketidakpedulian pemerintah terhadap rakyat miskin, sehingga rakyat miskin yang diwakili penyanyi jalanan tersebut ingin mengadakan pembalasan.

"Kita korban. Korban pemerintahan yang ndak bener. Korban pejabat yang serakah," kata yang lainnya lagi.

"Kita harus melawan. Jangan diam saja kalau sudah bisa makan," kata mereka lagi.

"Kita kerja keras cukup buat makan. Sementara di sana banyak orang tinggal ongkang-ongkang duitnya miliaran," kata yang lainnya. (PJ/KS/OM/2013/66)

Perlawanan selanjutnya yang dilakukan oleh Kalina seperti terlihat pada data selanjutnya, konteks situasinya adalah Kalina hamil dan menuntut pihak mandor untuk bertanggung jawab atas perbuatannya. Akan tetapi yang terjadi malah sebaliknya pihak mandor bukannya bertanggung jawab malah memecat Kalina dengan alasan yang tidak jelas.

"Saya bongkar semuanya sekarang! Biar semua orang di sini tahu!'Kini perempuan itu lari ke tengah ruangan, berdiri di meja terdepan.

"Mandor itu ... Mandor itu sudah memperkosa saya!'Perempuan itu bicara sambil menuding ke arah si mandor. Si mandor bergerak, menarik tangan perempuan itu tak bisa dibendung lagi. "Sekarang saya bunting, saya malah dipecat! Dasar binatang! Dia perkosa saya juga seperti binatang!” (PJ/KS/OM/2013/195)

Mahasiswa yang waktu itu berkumpul berangkat ke Jakarta bertekad untuk mengadakan perlawanan terhadap keadaan negara yang sedang mengalami krisis moneter yang berujung pada lengsernya status quo atau pemerintahan orde baru.

"Kami sedang ngumpulin orang buat berangkat ke Jakarta,"kata mereka setelah pembicaraan yang panjang. "Sampeyan mau?" 
Aku mengangguk. Apalagi yang perlu kupikirkan? Ini kesempatanku untuk berbuat sesuatu. Ini jalanku untuk juga bisa ikut melampiaskan kemarahanku. (PJ/KS/OM/2013/241)

\section{b. Makna Ujaran}

Konteks situasi merupakan praktik diskursif. Praktik diskursif ini akan memberikan pengaruh dan menentukan bagaimana teks diproduksi dan dikonsumsi. Teks yang dikonsumsi dapat diamati melalui maksud/ makna ujaran yang ada dalam teks yang mampu memberikan dukungan maksud ujaran yang terkait dengan konteks situasi tersebut.

Ada konteks situasinya menyuarakan tentang ketidakadilan pemerintah pada waktu itu sehingga berakibat kepada makna ujaran yang sama-sama tidak puas terhadap kepemimpinan Soeharto yang cenderung otoriter dan selalu memaksakan kehendak kepada rakyat jelata dan memaksa para mahasiswa waktu itu untuk turun ke jalan melakukan demonstrasi untuk menjatuhkan Presiden Soeharto.

Dari pertemuan-pertemuan itu aku jadi tahu banyak hal. Meski hanya diam, aku selalu mendengarkan setiap hal yang mereka bicarakan. Mereka selalu membeberkan kejahatan pemerintah yang tak pernah kuketahui sebelumnya. Mereka sebut Presiden Suharto sebagai pembunuh, penindas, dan koruptor. (PJ/MU/OM/2013/241)

\section{Tahap-Tahap Analisis Wacana Kritis (Dimensi Praksis Sosiokultural)}

Analisis ini merupakan dimensi terakhir dari tiga dimensi yang ditawarkan oleh Firclough. Aspek sosiokultural atau praksis sosiokultural didasarkan pada asumsi bahwa konteks yang ada di luar teks memengaruhi wacana yang muncul dalam teks. Praktik ini tidak berhubungan langsung dengan produksi teks tetapi menentukan cara teksyang diproduksi dan dipahami. Terdapat hubungan yang kompleks antara teks, wacana, dan konteks sosialnya.

Analisis sosiokultural dapat terlihat pada data bahwa tokoh Sasana masih mencintai musik dangdut yang merupakan musik asli Indonesia, meskipun dia harus melawan orang tuanya.

Aku masih merasa bergoyang di depan panggung, suara musik masih terdengar di telingaku. Pinggul bergoyang-goyang rasa ingin berdendang.... terus kusenandungkan dalam hati. Kemarahan Ibu tak juga bisa mengusir rasa senang yang baru aku dapatkan.

(PJ/Sb/OM/2013/20)

Pada data yang lain, penulis sengaja menggunakan bahasa Jawa sebagai wujud rasa cinta kepada bahasa daerah meskipun sekarang zaman globalisasi tetapi tidak boleh melupakan bahasa daerah yaitu bahasa Jawa sebagai bagian dari budaya bangsa.

"Ealah...berjuang kepriye...wong isone mung ngamen koyok ngene." jawab Cak Jek dengan nada mencibir. (PJ/Sb/OM/2013/67) 
Di sisi lain, penulis tidak hanya menyoroti terhadap realitas sosial ekonomi, musik, maupun bahasa tetapi juga terhadap politik yang masa itu selalu mempertahankan status quo. Akan tetapi berkat kegigihan para mahasiswa, status quo yang mengusung zaman orde baru pun tumbang digantikan zaman reformasi.

Pada hari ketika kami sama-sama meneriakkan kemenangan, aku meloncat-loncat kegirangan. Aku merasa sebagai bagian kemenangan itu. Tubuhku bergoyang di tengah-tengah ribuan orang. Tak akan ada lagi ketakutan, tak akan ada lagi orang-orang berlagak preman. Tak akan ada lagi anak SMA sok jagoan yang berlindung di balik jabatan bapaknya. Tak ada lagi tentara yang menyekap dan menyiksaku seenak mereka. Lebih dari itu, ini adalah kemenangan atas ketakutan. Ini adalah hari di mana impian akan kebebasan itu benar-benar datang.

$(\mathrm{PJ} / \mathrm{Sb} / \mathrm{OM} / 2013 / 243)$

\section{SIMPULAN}

Novel Pasung Jiwa karya Okky Madasari merupakan novel yang sangat menarik untuk dikaji karena novel ini banyak menggambarkan perlawanan yang dilakukan oleh tokoh-tokohnya untuk memperjuangan keadilan dan kebebasan. Dalam novel ini tampak adanya bentuk-bentuk perlawanan dan dianalisis dengan prosedur analisis wacana kritis (AWK).

Bentuk-bentuk perlawanan yang dilakukan tokoh dalam novel tersebut, meliputi: a). Perlawanan dalam bentuk perlawanan terbuka (public transcript) yaitu dalam bentuk demonstrasi atau unjuk rasa dan mogok kerja yang dilakukan secara berkelompok. b).Perlawanan dalam bentuk perlawanan tersembunyi atau tertutup (hidden transcript) yang diwujudkan dalam bentuk perlawanan secara individu untuk melepaskan diri dari jeratan.

Tahapan prosedur analisis wacana kritis meliputi beberapa hal. Pertama, dimensi teks (mikrostruktural). Aspek kelinguistikan memperlihatkan bahwa perlawanan dilakukan melalui kosa kata, gramatika, dan struktur teks yang membentuk kesatuan wacana. Perlawanan dalam aspek kelinguistikan tersebut berbentuk ideologi yang diperjuangkan dan direpresentasikan oleh kosa kata pada nilai pengalaman, nilai relasional, dan nilai ekspresif. Kedua, dimensi praksis kewacanaan (mesostruktural). Novel Pasung Jiwa karya Okky Madasari merupakan novel yang menyuarakan perlawanan melalui kontribusi proses produksi dan konsumsi teks. Latar belakang pengarang berpengaruh pada pemroduksian teks, sedangkan konsumen memaknai wacana tersebut sebagai bentuk perlawanan terhadap ketidakbebasan, ketidakadilan dan kesewenang-wenangan. Ketiga, dimensi praksis sosiokultural. Pada tataran sosiokultural, konteks sosial budaya yang ada di luar teks berpengaruh pada munculnya teks. Aspek sosiokultural tersebut tidak berhubungan langsung dengan produksi teks tetapi menentukan bagaimana teks diproduksi dan dipahami.

Secara situasional, Novel Pasung Jiwa karya Okky Madasari, bisa menjadi semacam cermin untuk menjadi seorang pemimpin yang bijak. 


\section{DAFTAR PUSTAKA}

Ahmadi, Abu.1997. Ilmu Sosial Dasar. Jakarta: Rineka Cipta.

Alwi, Hasan. 2005. Kamus Besar Bahasa Indonesia. Jakarta: Balai Pustaka.

Aminuddin. 1990. Pengembangan Penelitian Kualitatif dalam Bidang Bahasa dan Sastra. Malang : HISKI \& Yayasan Asah Asih Asuh.

Aminuddin. 1990. Sekitar Masalah Sastra. Malang: Yayasan Asah Asih Asuh.

Arikunto, Suhensi. 2002. Prosedur Penelitian: Suatu Pendekatan Praktek. Yogyakarta: Rineka Cipta.

Basrowi dan Sukidin, ed., 2003, Teori- teori perlawanan dan Kekerasan Kolektif. Surabaya: Insan Cendikia.

Damono, Sapardi Djoko. 2009. Sosiologi Sastra sebagai Pengantar Ringkas. Jakarta: P3B Depdikbud.

Darma, Yoce Aliah. 2009. Analisis Wacana Kritis. Bandung: Yrama Widya.

Endraswara, Suwardi. 2003. Metodologi Penelitian sastra (Epistemologi, Model, Teori, dan Aplikasi). Yogjakarta: Universitas Negeri Yogyakarta.

Fairclough, Norman. 1989. Language and Power. New York: Longman Group UK Limited.

Fairclough, Norman. 1995. Critical Discourse Analysis: The Critical Stusy of Language. London: Longman Group

Fairclough, Norman. 2003. Language and Power: Relasi Bahasa, Kekuasaan, dan Ideologi. England: Longman Group

Madasari, Okky. 2013. Novel Pasung Jiwa. Jakarta: Gramedia Pustaka Utama.

Mahayana, Maman S. 2005. 9 Jawaban Sastra Indonesia (Sebuah Orientasi Krtik). Jakarta: Bening Publishing

Mas'oed, Mochtar, 1998, Tantangan terhadap Integrasi Bangsa, Studi Kasus Konflik Sosial dan Kerusuhan Massa, Makalah, UGM, Yogyakarta.

Moloeng, Lexy J..2007. Metodologi Penelitian Kualitatif. Bandung: PT Remaja Rosdakarya.
Pradopo, Rachmat Djoko. 2002. Beberapa Teori Sastra, Metode Kritik, dan Penerapannya. Yogyakarta: Pustaka Pelajar.

Ratna, Nyoman Kutha. 2003. Paradigma Sosiologi Sastra. Yogyakarta: Pustaka Pelajar.

Ratna, Nyoman Kutha.2010. Sastra dan Cultural Studies: Representasi Fiksi dan Fakta. Yogyakarta: Pustaka Pelajar.

Saini, K.M. 1994. Protes Sosial dalam Sastra. Bandung: Angkasa.

Sangaji, Arianto. 2000. PLTA Lore Lindu: Orang Lindu Menolak Pindah, Yogyakarta: Pustaka Pelajar.

Santoso, Anang. 2003. Bahasa Politik Pasca Orde Baru. Jakarta: Wedatama Widya Sastra.

Santoso, Anang. 2006. Bahasa, Masyarakat, dan Kuasa: Topik-Topik Kritis dalam Ilmu Bahasa. Malang: Universitas Negeri Malang.

Soyomukti, Nurani. 2012. Satra Perlawanan.Malang: Beranda.

Sujinah. 2015. Pedoman Penulisan Tesis dan Artikel Ilmiah. Surabaya: Muhammadiyah University Press.

Sutopo, H.B. 2002. Penelitian Kualitatif. Surakarta: UNS Press.

Susan, Novri. 2010. Pengantar Sosiologi Konflik dan Isu-Isu Konflik Kontemporer. Jakarta: Kencana Prenada Media.

Tarrow, Sidney. 1994. Power in Movement, Social Movement, Collective Action and Politics, Cornell University.

Wellek, Renne dan Austin Warren. 1995. Teori

Kesusastraan (Diindonesiakan Oleh Melannie Budianta). Jakarta: Gramedia Pustaka Utama.

Wirawan, Ida Bagus. 2012. Teori-Teori Sosial dalam Tiga Paradigma (Fakta Sosial, Definisi Sosial, dan Perilaku Sosial). Jakarta: Kencana Prenada Media.

Yulianto, Bambang. 2009. Penuntun Praktis: Berbahasa Indonesia Dengan Baik dan Benar. Surabaya: Unesa University Press. 
Perlawanan Terhadap Dominasi Kekuasaan dalam Novel Pasung Jiwa Karya Okky Madasari (Analisis Wacana Kritis)

Zubir, Zaiyardam. 2002, Radikalime Kaum

Pinggiran: Studi tentang Idiologi,

Isu, Strategi, dan Dampak Gerakan.

Yogyakarta: Insist Press 